\title{
Konferencja „Nauczanie domowe dzieci na ziemiach polskich w XIX i na początku XX wieku. Zapatrywania teoretyczne i praktyka". Pieczyska, 18 - 19 września 2003 r.
}

W dniach 18 - 19 września 2003 roku w Pieczyskach odbyła się konferencja naukowa, której tematyka było Nauczanie domowe dzieci na ziemiach polskich w XIX i na poczatku XX wieku. Zapatrywania teoretyczne i praktyka.

Konferencja ściagnęła do tego malowniczo położonego miejsca szanowane postacie z grona polskich historyków wychowania.

Referenci uczestniczący w sesji reprezentowali następujace ośrodki: Uniwersytet Warszawski, Instytut Historii Nauki PAN w Warszawie, Akademię Pedagogiki Specjalnej w Warszawie, UMCS w Lublinie, Uniwersytet Wrockawski, Akademię Pedagogiczną w Krakowie, Uniwersytet Śląski w Katowicach, Uniwersytet w Białymstoku, AWF w Gdańsku, Uniwersytet Eódzki, UMK w Toruniu, UAM w Poznaniu, Akademię Bydgoska.

Organizatorem konferencji był Zakład Historii Myśli i Doktryn Pedagogicznych AB. Konferencję zorganizowano w ramach realizacji projektu badawczego KBN nr 2 H01 F 01522.

Przybyłych gości powitał i konferencję otworzył prof. dr hab. Krzysztof Jakubiak, dziękując zebranym za liczne przybycie i zainteresowanie problematyka spotkania.

W części przedpołudniowej obradom przewodniczyła prof. dr hab. Irena Szybiak. Obrady zainaugurował wykład prof. dr hab. K. Jakubiaka. Referent przedstawił stan i potrzeby badań nad nauczaniem domowym dzieci na ziemiach polskich od XVIII do początków XX wieku. Następnie głos zabrał prof. dr hab. Juliusz Jundziłł, który jako badacz epoki starożytnej, zaprezentował ciekawy referat poświęcony problematyce kształcenia domowego z pozycji starożytnika pt.: Przeciwko Kwintylianowi - kszatcenie domowe $w$ starozytności.

Następny referent - dr Adam Winiarz zapoznał słuchaczy ze swoimi zaawansowanymi badaniami nad problematyką nauczania domowego dzieci polskich w dobie niewoli narodowej. Referent ujawnił wiele nowych, nieznanych dotąd, faktów dotyczących omawianej problematyki, a także przedstawił plan dalszych badań, które zmierzaja do opracowania mapki z wyznaczonymi miejscami organizowania nauczania domowego na ziemiach polskich $w$ dobie zaborów.

Prof. dr hab. Krystyna Wróbel-Lipowa skupiła się na omówieniu organizacji i przebiegu nauki domowej możnowladztwa i ziemiaństwa polskiego w XIX wieku.

Następna referentka - prof. dr hab. Kalina Bartnicka, zwrócila uwagę na substytut wychowania domowego, jakim były w XIX wieku pensje żeńskie. Wśród wielu omawianych zagadnień, referentka omówiła organizację, funkcjonowanie oraz programy nauczania $w$ tychże instytucjach $w$ pierwszym dwudziestoleciu XIX wieku. Pierwsza część obrad zakończył referat prof. dr hab. Karola Poznańskiego, który przedstawił zagadnienie nauczania domowego i prywatnego w Królestwie Polskim w świetle ówczesnego prawodawstwa. Jeśli chodzi o cezurę czasową omawianej problematyki referent skupil się na okresie międzypowstaniowym.

Druga część obrad, prowadzonych już przez prof. dr hab. Danutę Dryndę, rozpoczął dr Kazimierz Adamczyk. Referent omówił problematykę nauczania domowego na przykładzie edukacji, jaką odebrał Wladysław Zamoyski. Podzielił się ze słuchaczami ciekawostkami dotyczacymi nauki domowej W. Zamoyskiego. Wzory edukacji domowej w XIX-wiecznej literaturze dla dzieci i młodzieży omówił obszernie i w oparciu o ciekawe przykłady literackie dr Ryszard Waksmund.

Problematykę edukacji domowej dzieci w polskich domach ziemiańskich na Ukrainie w drugiej połowie XIX wieku przedstawił dr Tadeusz Epsztein. Referent w swym wystapieniu skupił się na omówieniu wpływu zainteresowań intelektualnych rodziców na edukację domowa dzieci. Kolejny referat na temat organizacji, doboru przedmiotów i treści oraz metod nauczania domowego 
w Królestwie Polskim wygłosiła mgr Monika Nawrot. Referentka omówiła wymienione zagadnienia w świetle źródeł pamiętnikarskich z XIX i poczatków XX wieku.

Następnie głos zabrali dr Jan Ryś i dr Ryszard Ślęczka, którzy przedstawili referat pt.: Elementarze do nauczania domowego z drugiej polowy XIX wieku. Prof. dr hab. Agnieszka Stopińska-Pająk zwróciła uwagę w swym wystapieniu na znaczenie kalendarzy w rodzinnym nauczaniu domowym na Górnym Śląsku. Ostatni w tej części obrad referat wygłosiła mgr Agnieszka Szarkowska, która skupiła się na roli wychowania religijnego $\mathrm{w}$ nauczaniu domowym dzieci w okresie zaborów.

Drugi dzień obrad, którym przewodniczyła prof. dr hab. Alicja Kicowska, rozpoczał referat prof. dr hab. Romualda Grzybowskiego na temat udziału prasy w nauczaniu domowym dzieci polskich na Pomorzu Nadwiślańskim w drugiej połowie XIX i pierwszych latach XX wieku. Prof. dr hab. Grzegorz Michalski zwrócił uwage na wskazania dla edukacji domowej, jakie można odnaleźć w polskim czasopiśmiennictwie drugiej połowy XIX wieku i w pierwszych latach XX wieku.

Prof. dr hab. Władysława Szulakiewicz postawiła w swym referacie pytanie o istotę i specyfike zawodu nauczyciela domowego.

Następnie głos zabrała dr Katarzyna Kabacińska, która przedstawiła referat pt.: Nauczyciel domowy - ideat a rzeczywistość.

Tę część obrad zakończyło wystapienie mgr Grażyny Karłowskiej, która przedstawiła, w formie prezentacji multimedialnej, charakterystykę nauczycieli domowych na ziemiach polskich $w$ XIX i na poczatku XX wieku.

Ostatnią część obrad poprowadził prof. dr hab. Karol Poznański. Jako pierwszy w tej części obrad referat wygłosił prof. dr hab. Tadeusz Jałmużna. Referent poświęcił go w całości analizie zagadnienia nauczania domowego w twórczości Henryka Wernica. Z kolei dr Iwonna Michalska zwróciła uwagę na wkład twórczości Teofila Nowosielskiego do edukacji domowej.

Dwa ostatnie referaty przedstawiały zagadnienie nauczania domowego ze stanowiska socjologicznego i współczesnej myśli pedagogicznej. Dr Marek Budajczak zwrócił uwagę na społeczne dawne i współczesne wymiary edukacji domowej, natomiast dr Roman Leppert omówił historyczne i religijne źródła współczesnego nauczania domowego w USA.

Podsumowania konferencji dokonał prof. dr hab. Karol Poznański, który podkreślił wysoki poziom konferencji, zwrócił uwage na aktualność problematyki nauczania domowego í potrzebę dalszego prowadzenia badań w tym zakresie.

Grażyna Kartowska

\section{Konferencja „Rozwój pedagogiki jako nauki i kierunku studiów na Słowacji”. Bratysława, 22-23 września 2003 r.}

W dniach 22 - 23 września 2003 roku na Uniwersytecie im. J. A. Komeńskiego w Bratysławie odbyła się konferencja naukowa, której tematyką był Rozwój pedagogiki jako nauki i kierunku studiów na Slowacji.

Konferencja miała charakter międzynarodowy, a wśród jej uczestników znaleźli się naukowcy nie tylko ze Słowacji, ale między innymi z Czech, Polski, Chorwacji.

Organizatorem konferencji była Katedra Pedagogiki Uniwersytetu Komeńskiego w Bratysławie. Otwarcia konferencji dokonała kierownik Katedry Pedagogiki Uniwersytetu Komeńskiego - doc. Z. Baduriková. Przybyłych gości powitał również dziekan Wydziału Filozoficznego Uniwersytetu Komeńskiego w Bratysławie - doc. Anton Eliâs. Wykład inauguracyjny o seminarium pedagogicznym na Uniwersytecie Komeńskiego w kontekście rozwoju myśli pedagogicznej na Słowacji, wygłosił prof. Jozef Pš̃enák. Następnie głos zabral prof. Štefan Švec, który mówil o potrzebie pedagoga szkolnego. 